\title{
Pedobacter duraquae sp. nov., Pedobacter westerhofensis sp. nov., Pedobacter metabolipauper sp. nov., Pedobacter hartonius sp. nov. and Pedobacter steynii sp. nov., isolated from a hard-water rivulet
}

\author{
Sören Muurholm, Sylvie Cousin, Orsola Päuker, Evelyne Brambilla \\ and Erko Stackebrandt

\begin{abstract}
DSMZ - Deutsche Sammlung von Mikroorganismen und Zellkulturen GmbH, Inhoffenstrasse 7b, D-38124 Braunschweig, Germany
\end{abstract}

Correspondence

Sylvie Cousin

sylvie.cousin@dsmz.de

\begin{abstract}
Five isolates that were related phylogenetically to members of the genus Pedobacter were isolated from freshwater of the hard-water creek Westerhöfer Bach, North Germany. The five strains (WB 2.1-25 $5^{\top}$, WB 2.3-71 ${ }^{\top}$, WB 3.3-3 ${ }^{\top}$, WB 3.3-22 $2^{\top}$ and WB 2.3-45 ${ }^{\top}$ ) were Gram-negative and chemoheterotrophic, with rod-shaped cells. Most of their metabolic properties matched those given in the description of the genus Pedobacter. Consistent with the genus description, their fatty acids included mainly iso- $C_{15: 0}$ and summed feature $3\left(C_{16: 1} \omega 7 c\right.$, iso- $\mathrm{C}_{15: 0} 2-\mathrm{OH}$ or both); $\mathrm{C}_{16: 1} \omega 5 c, \mathrm{C}_{16: 0}$, iso- $\mathrm{C}_{15: 0} 3-\mathrm{OH}, \mathrm{C}_{16: 0} 3-\mathrm{OH}$ and iso- $\mathrm{C}_{17: 0} 3-\mathrm{OH}$ were present in smaller amounts. The major isoprenoid quinone was menaquinone 7 . With one exception, binary similarity values of the almost complete 16S rRNA gene sequences determined among the isolates as well as between the isolates and type strains of Pedobacter species were lower than $98.5 \%$. The only exception was the close relationship between Pedobacter caeni DSM $16990^{\top}$ and strain WB $2.3-45^{\top}$ (99.2\% similarity). DNA-DNA reassociation values determined for this pair of strains was $29.8 \%$, indicating that strain WB $2.3-45^{\top}$ represents a unique genospecies. Phylogenetic analysis based on $16 \mathrm{~S}$ rRNA gene sequences indicated that strains WB $2.1-25^{\top}$ and WB $2.3-71^{\top}$ form a group that is moderately related to $P$. caeni and strain WB $2.3-45^{\top}$ (98.5 \% similarity). Strains WB 3.3-3 ${ }^{\top}$ and WB 3.3-22 $2^{\top}$ ( $98.5 \%$ similarity) branched separately from these four organisms. The five phylogenetically isolated strains differed from each other as well as from the type strain of the type species (Pedobacter heparinus DSM 2366 ${ }^{\top}$ ) and some related representatives of the genus in several metabolic reactions and cultural parameters. On the basis of phenotypic and phylogenetic distinctiveness, five novel species are proposed: Pedobacter duraquae sp. nov., with WB 2.1-25 ${ }^{\top}$ $\left(=\mathrm{DSM} 19034^{\top}=\mathrm{CIP} 109481^{\top}\right)$ as the type strain; Pedobacter westerhofensis sp. nov., with WB 3.3-22 $2^{\top}$ (=DSM $19036^{\top}=$ CIP $109479^{\top}$ ) as the type strain; Pedobacter metabolipauper sp. nov., with WB $2.3-71^{\top}\left(=\mathrm{DSM} 19035^{\top}=\mathrm{CIP} 109480^{\top}\right)$ as the type strain; Pedobacter hartonius sp. nov., with WB 3.3-3 $3^{\top}\left(=\mathrm{DSM} 19033^{\top}=\right.$ CIP $\left.109468^{\top}\right)$ as the type strain; and Pedobacter steynii sp. nov., with WB $2.3-45^{\top}\left(=\mathrm{DSM} 19110^{\top}=\mathrm{CIP} 109507^{\top}\right)$ as the type strain.
\end{abstract}

The genus Pedobacter (Steyn et al., 1998) was established to accommodate Sphingobacterium heparinum (Takeuchi \& Yokota, 1992) and some other heparinolytic bacteria that, on the basis of DNA-DNA hybridization (Steyn et al.,

The GenBank/EMBL/DDBJ accession numbers for the 16S rRNA gene sequences of strains WB $2.1-25^{\top}$, WB 3.3-22 ${ }^{\top}$, WB $2.3-71^{\top}$, WB 3.3-3 ${ }^{\top}$ and WB 2.3-45 ${ }^{\top}$ are AM491368-AM491372, respectively.

A table showing antibiotic sensitivities of the Pedobacter WB isolates is available as supplementary material with the online version of this paper.
1992, 1993), were shown to fall outside the realm of the genus Sphingobacterium. Several novel species have been added to the genus Pedobacter during the past few years, isolated mainly from soil (Ten et al., 2006; Yoon et al., 2007), freshwater (Gallego et al., 2006; Hwang et al., 2006; Vanparys et al., 2005) and glaciers (Margesin et al., 2003; Shivaji et al., 2005). During a recent survey on the microbial composition of a hard-water creek, almost 1000 strains were isolated on R2A agar, about $50 \%$ of which had swarming $(40 \%)$ or slime-producing $(10 \%)$ 
capacities. Whereas almost all of the swarming bacteria and many slime-formers could be affiliated to the genus Flavobacterium (Brambilla et al., 2007; Cousin et al., 2007), other slime-producing organisms were members of different proteobacterial taxa (Stackebrandt et al., 2007; unpublished data) and of the phylum Bacteroidetes (unpublished data). Among the latter organisms, five strains, identified by partial $16 \mathrm{~S}$ rRNA gene sequences as members of the genus Pedobacter, were subjected to a polyphasic taxonomic study; subsequently, all were described as representatives of novel species.

The isolation of strains from the Westerhöfer Bach on medium R2A (Difco) has been described by Brambilla et al. (2007). Strains WB $2.1-25^{\mathrm{T}}, \mathrm{WB} 2.3-71^{\mathrm{T}}$ and WB $2.3-45^{\mathrm{T}}$ were isolated about $180 \mathrm{~m}$ downstream of the spring (station 2; station 1 being the source of Westerhöfer Bach), whereas strains WB $3.3-3^{\mathrm{T}}$ and WB $3.3-22^{\mathrm{T}}$ were isolated about $250 \mathrm{~m}$ downstream of the spring (station 3 ). Following isolation, strains were transferred and maintained on medium 67 (M67; DSMZ, 2001) at $25{ }^{\circ} \mathrm{C}$ for several days. The same medium was also used to cultivate the reference strains Pedobacter heparinus DSM 2366 ${ }^{\mathrm{T}}$, Pedobacter africanus DSM $12126^{\mathrm{T}}$, Pedobacter caeni DSM $16990^{\mathrm{T}}$ and Pedobacter cryoconitis DSM $14825^{\mathrm{T}}$. Maintenance in glycerol served as a medium-term preservation method. Cultures were preserved in liquid $\mathrm{N}_{2}$ and freeze-dried.

DNA extraction and PCR amplification of the 16S rRNA genes were carried out as described by Rainey et al. (1996). The PCR amplificons were purified by using the QIAquick PCR Purification kit (QIAGEN) according to the instructions of the manufacturer. Sequencing of the PCR products, manual alignment of the sequences with those of Pedobacter type strains and determination of similarity coefficients were done as described by Rainey et al. (1996). The algorithm of De Soete (1983) and the neighbour-joining algorithm (Felsenstein, 1993) were used to generate tree topologies.

Binary similarity values of the almost complete sequences of the 16S rRNA gene, determined for the five WB strains, were lower than $98.5 \%$. Two strain clusters emerged from the analysis, one containing strains WB $2.1-25^{\mathrm{T}}$, WB 2.3$71^{\mathrm{T}}$ and WB $2.3-45^{\mathrm{T}}(97.7-98.5 \%$ similarity $)$ and the other containing strains $\mathrm{WB} \quad 3.3-3^{\mathrm{T}}$ and $\mathrm{WB} \quad 3.3-22^{\mathrm{T}}(98.5 \%$ similarity). The similarity values between the two groups were $95.8-97.0 \%$. With the exception of P. caeni DSM $16990^{\mathrm{T}}$, which shared a $16 \mathrm{~S}$ rRNA gene sequence similarity value of $99.2 \%$ with strain WB $2.3-45^{\mathrm{T}}$, the type strains of other Pedobacter species were more distantly related to the isolates (91.5-98.2\% similarity). P. caeni DSM $16990^{\mathrm{T}}, P$. africanus DSM $12126^{\mathrm{T}}$ and P. cryoconitis DSM $14825^{\mathrm{T}}$ were included in the following studies because they showed the highest similarity values with the novel WB strains. $P$. heparinus DSM $2366^{\mathrm{T}}$ was included as the type strain of the type species of the genus. Phylogenetic relationships of the novel strains to other Pedobacter species type strains are shown in a phylogenetic tree (Fig. 1) generated based on the algorithm of De Soete (1983). Topologies of the neighbour-joining and maximum-likelihood trees differed slightly in the branching points of the deeply branching clades (not shown), but the affiliation of phylogenetic neighbours are in accord with those published previously (Gallego et al., 2006; Margesin et al., 2003; Shivaji et al., 2005; Ten et al., 2006; Yoon et al. 2007).

Literature data compiled from hundreds of species descriptions in 2005 indicated that strains sharing less than $98.8 \%$ sequence similarity belong to different genospecies (Stackebrandt \& Ebers, 2006); however, values above this threshold value are not necessarily indicative of novel genospecies. Therefore, the genomic relatedness between $P$. caeni $16990^{\mathrm{T}}$ and WB $2.3-45^{\mathrm{T}}$ was determined by using the spectrophotometric DNA-DNA reassociation method. DNA was isolated using a French pressure cell (Thermo Spectronic) and was purified by hydroxyapatite chromatography as described by Cashion et al. (1977). DNA-DNA hybridization was carried out as described by De Ley et al. (1970), with the modifications of Huß et al. (1983) and Escara \& Hutton (1980), using a model Cary 100 Bio UV/VIS-spectrophotometer equipped with a

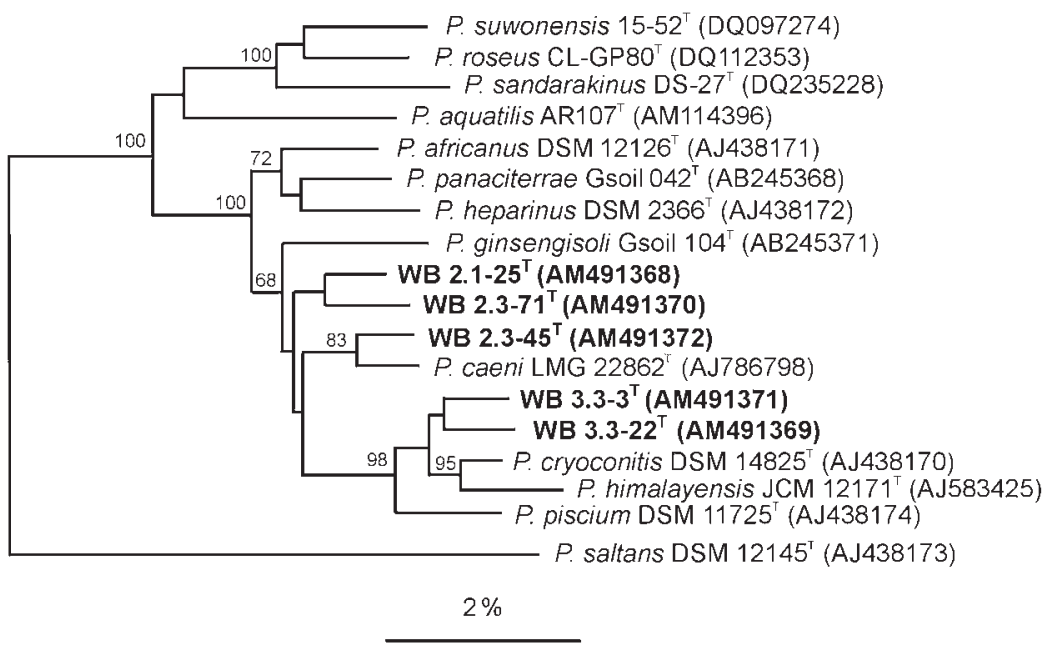

Fig. 1. Relationship of the WB isolates to type strains of Pedobacter species. The dendrogram is based on 16S rRNA gene sequence comparisons using the algorithm of De Soete (1983). Bar, $2 \%$ sequence divergence, as determined by measuring the length of the horizontal lines connecting any two species. 
Peltier-thermostatted $6 \times 6$ multicell changer and a temperature controller with in situ temperature probe (Varian). Two reassociation experiments resulted in 35.7 and $23.9 \%$ reassociation (mean of $29.8 \%$ ). These low values indicate that strain WB $2.3-45^{\mathrm{T}}$ represents a novel genospecies.

The novel strains and some Pedobacter reference strains were subjected to fatty acid methyl ester analysis to confirm membership to the genus. Cultures of all strains were grown on trypticase soy agar (TSA; Difco) for 24 h. Fatty acids were extracted and analysed (Miller, 1982) according to the standard protocol of the Microbial Identification System (MIS; MIDI Microbial ID). Extracts were analysed using a Hewlett Packard model HP6890A GC equipped with an FID as described by Kämpfer \& Kroppenstedt (1996). The major fatty acids were summed feature 3 $\left(\mathrm{C}_{16: 1} \omega 7 c\right.$, iso- $\mathrm{C}_{15: 0} 2-\mathrm{OH}$ or both) (35-48\% of total) and iso- $\mathrm{C}_{15: 0}(15-26.5 \%) ; \mathrm{C}_{16: 1} \omega 5 c, \mathrm{C}_{16: 0}$, iso- $\mathrm{C}_{15: 0} 3-\mathrm{OH}$, $\mathrm{C}_{16: 0} 3-\mathrm{OH}$ and iso- $\mathrm{C}_{17: 0} 3-\mathrm{OH}$ were present in smaller amounts. The amounts of fatty acids determined in the analysed reference strains agreed by and large with the values indicated in the literature (e.g. Steyn et al., 1998; Gallego et al., 2006). A dendrogram of fatty acid relationships is shown in Fig. 2. Although most strains differed in the quantities of their fatty acids only, the separation of $P$. heparinus DSM $2366^{\mathrm{T}}$ and $P$. africanus DSM $12126^{\mathrm{T}}$ from P. cryoconitis DSM $14825^{\mathrm{T}}$, P. caeni DSM $16990^{\mathrm{T}}$ and the $\mathrm{WB}$ strains is in accord with the 16S rRNA gene tree (Fig. 1), as is the position of strain WB $2.3-45^{\mathrm{T}}$ adjacent to the type strain of $P$. caeni. Menaquinones were determined according to Minnikin et al. (1984). MK-7 was the major peak $(97-100 \%)$ in all strains tested.

To test whether the novel genospecies could also be defined in terms of distinguishing phenotypic properties, strains were subjected to cultural, biochemical and morphological analyses. Results are indicated in Table 1 and the species description. All strains were grown on R2A medium. Strains WB 2.1-25 $5^{\mathrm{T}}$, WB $2.3-45^{\mathrm{T}}$, WB $2.3-71^{\mathrm{T}}$, WB $3.3-22^{\mathrm{T}}$, $P$. africanus DSM $12126^{\mathrm{T}}$, P. caeni DSM $16990^{\mathrm{T}}$ and $P$. heparinus DSM $2366^{\mathrm{T}}$ were grown at $25^{\circ} \mathrm{C}$, whereas strain WB $3.3-3^{\mathrm{T}}$ and P. cryoconitis DSM $14825^{\mathrm{T}}$ were grown at $20{ }^{\circ} \mathrm{C}$. Growth was measured by reading the $\mathrm{OD}$ at $600 \mathrm{~nm}$. The temperature optimum was tested over a period of 3-6 days using a temperature gradient incubator model TN-3 (Toyo Kagaku Sangyo) at $1-36{ }^{\circ} \mathrm{C}$ in steps of $2{ }^{\circ} \mathrm{C}$. The optimal $\mathrm{pH}$ for growth was tested in buffered $\mathrm{M} 67$ at $25{ }^{\circ} \mathrm{C}$ at $\mathrm{pH} 4.0-9.5$ in steps of $0.2 \mathrm{pH}$ units using three different buffer solutions $\left(\mathrm{Na}_{2} \mathrm{HPO}_{4} / \mathrm{NaH}_{2} \mathrm{PO}_{4}\right.$, succinic acid/ $\mathrm{NaOH}$ and 2-amino-2-methyl-1,3-propanediol/HCl). Analysis was done at 1 day intervals over a period of 6 days. Salt tolerance was tested on R2A medium supplemented with $1-10 \% \mathrm{NaCl}$ in steps of $2 \%$.

Morphology of cells grown on R2A media for $6 \mathrm{~h}, 30 \mathrm{~h}$ and 8 days was investigated by light microscopy at $2400 \times$ magnification. Colony morphology was determined after $24 \mathrm{~h}, 5$ days and 14 days at optimal growth temperature on media R2A, nutrient agar (NA; Difco) and TSA. Growth was also determined on MacConkey agar (Difco). Microaerophilic growth was tested on R2A plates in a candle jar for 3 days at $23{ }^{\circ} \mathrm{C}$ (Gerhardt et al., 1981). Cells were tested for gliding movement by the hanging drop method as described by Bernardet et al. (2002); motility was tested with cells from 2-day-old liquid cultures on soft agar incubated for 3 days at $23{ }^{\circ} \mathrm{C}$. The presence of flexirubin pigments (Bernardet et al., 2002), Gram-stain using the aminopeptidase and $\mathrm{KOH}$ reactions, catalase activity $\left(\mathrm{H}_{2} \mathrm{O}_{2}\right.$ test) and heparin hydrolysis (Zimmermann et al., 1990) were also tested. Cytochrome $c$ oxidase was determined by adding a few drops of tetramethyl- $p$ phenylenediamine solution to a 3-day-old slant of each strain. All WB isolates were aerophilic and microaerophilic under the conditions provided in a candle jar, non-gliding and motile.

Antimicrobial susceptibilities were determined with the disc diffusion method using a ST6090 Disc Dispenser (Oxoid). Isolates were classified into three categories (sensitive, resistant and intermediate) based on the quantitative interpretation criteria recommended by the NCCLS (2000). All strains studied were resistant to cefalotin $(30 \mu \mathrm{g})$, cefotaxime $(30 \mu \mathrm{g})$, oxacillin $(5 \mu \mathrm{g})$, mezlocillin $(30 \mu \mathrm{g})$, aztreonam $(30 \mu \mathrm{g})$, gentamicin $(10 \mu \mathrm{g})$, colistin $(10 \mu \mathrm{g})$, vancomycin $(30 \mu \mathrm{g})$, amikacin $(30 \mu \mathrm{g})$, polymyxin $\mathrm{B}(300 \mathrm{IU})$, kanamycin $(30 \mu \mathrm{g})$ and neomycin $(30 \mu \mathrm{g})$; all were sensitive to doxycycline $(30 \mu \mathrm{g})$, imipenem $(10 \mu \mathrm{g})$ and tetracycline $(30 \mu \mathrm{g})$. Results in which the WB strains differ from each other

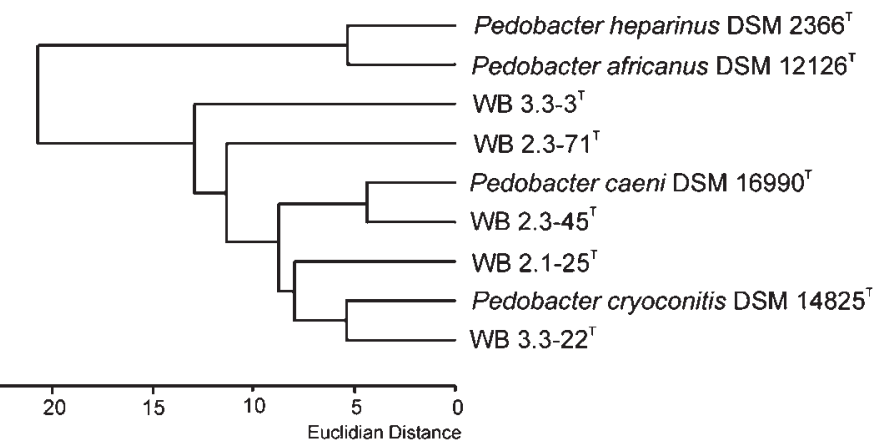

Fig. 2. Dendrogram showing the fatty acid relationships among the WB isolates and phylogenetically neighbouring Pedobacter reference strains. The dendrogram was generated by treating the Euclidian distances of the fatty acids with the unweighted pair group method with arithmetic means algorithm. Numerical analyses were done using standard MIS software (Microbial ID). 
Table 1. Differential biochemical properties of the Pedobacter WB isolates and phylogenetically related Pedobacter type strains

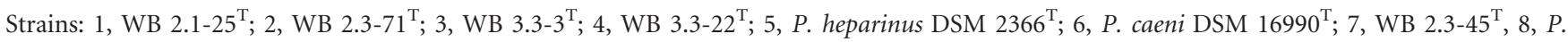
cryoconitis DSM $14825^{\mathrm{T}}$; 9, P. africanus DSM $12126^{\mathrm{T}}$. All strains are positive for the following features: aminopeptidase, KOH test, catalase, oxidase, $N$-acetyl- $\beta$-glucosaminidase, $\alpha$-D-lactose, D-melibiose, trehalose, alkaline phosphatase, leucine arylamidase, $\beta$-glucosidase, esterase lipase (C8), naphthol-AS-BI-phosphohydrolase and $\beta$-galactosidase. All strains tolerate up to $2 \% \mathrm{NaCl}$, hydrolyse Tween 80 , aesculin and starch, and assimilate the following substrates: D-mannose, D-glucose, L-arabinose, methyl $\alpha$-D-glucopyranoside, arbutin, aesculin, ferric citrate, amidon, D-cellobiose, maltose and D-turanose. All strains are negative for the following features: nitrate reduction, indole production, glucose fermentation, arginine dihydrolase, lipase (C14), cystine arylamidase, $\alpha$-mannosidase, $\alpha$-fucosidase, flexirubin reaction with $20 \% \mathrm{KOH}$, gelatinase and urease. The following substrates are not assimilated: L-proline, malate, citrate, L-alanine, L-alanyl glycine, L-asparagine, L-aspartic acid, DL- $\alpha$-glycerol phosphate, Tween 40, adonitol, D-arabitol, i-erythritol, myo-inositol, L-rhamnose, pyruvic acid methyl ester, succinic acid monomethyl ester, acetic acid, cisaconitic acid, citric acid, formic acid, D-galactonic acid lactone, D-galacturonic acid, D-gluconic acid, D-glucosaminic acid, $\alpha$-hydroxybutyric acid, $\beta$-hydroxybutyric acid, $p$-hydroxyphenylacetic acid, itaconic acid, $\alpha$-ketobutyric acid, $\alpha$-ketoglutaric acid, $\alpha$-ketovaleric acid, DL-lactic acid, malonic acid, propionic acid, quinic acid, D-saccharic acid, sebacic acid, bromosuccinic acid, succinamic acid, glucuronamide, alaninamide, D-alanine, Lhistidine, hydroxy-L-proline, L-leucine, L-ornithine, L-phenylalanine, L-pyroglutamic acid, D-serine, DL-carnitine, $\gamma$-aminobutyric acid, urocanic acid, inosine, uridine, thymidine, phenylethylamine, putrescine, 2-aminoethanol, 2,3-butanediol, glucose 6-phosphate, methyl $\beta$-D-xylopyranoside, L-dulcitol, D-melezitose, xylitol, D-tagatose, D-fucose, L-fucose, L-arabitol, 2-ketogluconate, 5-ketogluconate, gluconate, capric acid, adipic acid and phenylacetic acid. +, Positive; -, negative; w, weak reaction; v, variable.

\begin{tabular}{|c|c|c|c|c|c|c|c|c|c|}
\hline Utilization of: & 1 & 2 & 3 & 4 & 5 & 6 & 7 & 8 & 9 \\
\hline \multicolumn{10}{|l|}{ API $50 \mathrm{CH}$ and API 20NE } \\
\hline Amygdalin & + & - & + & - & $-(+)^{*}$ & + & - & - & $-(+)^{*}$ \\
\hline D-Arabitol & - & - & + & - & - & - & - & - & - \\
\hline D-Ribose & + & - & - & - & - & - & - & - & - \\
\hline D-Xylose & + & - & + & + & + & $+(-)^{*}$ & + & + & + \\
\hline D-Adonitol & + & - & - & - & $-(+)^{*}$ & - & - & - & - \\
\hline Gentiobiose & + & + & + & + & $-(+)^{*}$ & + & + & + & $+(5 / 6)^{*}$ \\
\hline Inulin & + & - & - & - & - & - & - & $\mathrm{W}$ & - \\
\hline L-Rhamnose & + & - & + & + & + & - & - & - & + \\
\hline Salicin & + & - & + & - & $-(+)^{*}$ & + & + & $-(+)^{*}$ & $+(4 / 6)^{*}$ \\
\hline Methyl $\alpha$-D-mannopyranoside & - & + & - & + & $-(+)^{*}$ & + & - & - & + \\
\hline$N$-Acetyl-D-glucosamine & - & - & + & W & + & + & + & - & + \\
\hline D-Fructose & + & - & + & $-(+) \dagger$ & + & - & - & + & $-(2 / 6)^{\star}$ \\
\hline D-Mannitol & - & - & $+(-) \dagger$ & - & $-(+)^{*} \dagger$ & $-(+) \dagger$ & - & - & - \\
\hline D-Galactose & + & - & + & + & $-(+)^{\star} \dagger$ & - & + & + & - \\
\hline Sucrose & + & $+(-) \dagger$ & - & + & $-(+)^{*}$ & + & - & + & + \\
\hline D-Sorbitol & - & - & - & - & + & - & - & - & - \\
\hline D-Raffinose & $+(-) \dagger$ & - & - & $+(-) \dagger$ & $+(-)^{*}$ & + & $+(-) \dagger$ & $+(-)^{*}$ & - \\
\hline Glycerol & - & - & - & + & - & $+(-)^{*}$ & + & $-(+)^{*}$ & - \\
\hline Glycogen & - & - & - & - & - & - & + & + & - \\
\hline \multicolumn{10}{|l|}{ Biolog } \\
\hline D-Arabinose & + & - & - & - & - & - & - & - & - \\
\hline$\alpha$-Cyclodextrin & + & - & - & $\mathrm{W}$ & - & + & + & + & - \\
\hline Dextrin & + & - & $\mathrm{w}$ & + & - & + & + & + & - \\
\hline$N$-Acetyl-D-galactosamine & - & - & - & - & - & + & - & - & - \\
\hline L-Arabinose & - & - & $\mathrm{w}$ & $\mathrm{w}$ & $-(+)^{*}$ & + & - & $-(+)^{*}$ & - \\
\hline Lactulose & - & - & $\mathrm{w}$ & + & W & + & + & - & - \\
\hline Methyl $\beta$-D-glucoside & - & - & + & + & $-(+)^{*}$ & + & + & $+(\mathrm{w})^{*}$ & - \\
\hline Psicose & - & - & - & $\mathrm{w}$ & - & - & - & - & - \\
\hline D-Glucuronic acid & - & - & - & - & - & $\mathrm{w}$ & - & - & - \\
\hline Succinic acid & - & - & - & - & - & $\mathrm{w}$ & - & - & - \\
\hline L-Glutamic acid & - & - & - & - & - & + & + & + & - \\
\hline Glycyl L-aspartic acid & - & - & - & - & - & + & $\mathrm{w}$ & - & + \\
\hline Glycyl L-glutamic acid & - & - & - & - & - & + & $\mathrm{w}$ & - & + \\
\hline L-Serine & - & - & - & + & $-(\mathrm{v})^{*}$ & $\mathrm{~W}$ & + & $\mathrm{W}$ & - \\
\hline
\end{tabular}


Table 1. cont.

\begin{tabular}{|lllllllllll}
\hline Utilization of: & $\mathbf{1}$ & $\mathbf{2}$ & $\mathbf{3}$ & $\mathbf{4}$ & $\mathbf{5}$ & $\mathbf{6}$ & $\mathbf{7}$ & $\mathbf{8}$ & $\mathbf{9}$ \\
\hline L-Threonine & - & - & - & $\mathrm{w}$ & $-(\mathrm{v})^{*}$ & + & + & - \\
Glucose 1-phosphate & - & - & - & - & - & - & - & - \\
\hline
\end{tabular}

${ }^{\star}$ Reactions in parentheses are as given in the original description. For P. africanus (Steyn et al., 1998), the type strain has not been recorded individually so the number of positive scoring strains is indicated in parentheses.

$\dagger$ Reactions in parentheses according to Biolog.

are presented in Supplementary Table S1 available in IJSEM Online.

Enzymic activities and carbon assimilation tests were determined using the commercial API ZYM, API $50 \mathrm{CH}$ and API 20NE systems (bioMérieux) and the utilization or oxidization of carbon sources was determined using the GN MicroPlate system (Biolog) according to the instructions of the manufacturers. A modified AUX media (Somvanchi et al., 2006) with $0.6 \mathrm{~g} \mathrm{MgSO} 4.7 \mathrm{H}_{2} \mathrm{O}$ instead of $6 \mathrm{~g}$ was used for strain WB $2 \cdot 1-25^{\mathrm{T}}$. API ZYM tests were read after $6 \mathrm{~h}$ incubation, whereas API $50 \mathrm{CH}$, API 20NE and GN MicroPlate tests were read after $48 \mathrm{~h}$. Incubation was at $25{ }^{\circ} \mathrm{C}$ except for P. cryoconitis DSM $14825^{\mathrm{T}}$ and strain WB $3.3-3^{\mathrm{T}}$, which were inoculated at $20{ }^{\circ} \mathrm{C}$. Results are included in the species descriptions and Table 1.

Many of the reactions indicated as positive for all strains of the genus Pedobacter also scored positive in our tests (Table 1). Some other substrates were used by the majority of strains, i.e. D-xylose, sucrose, gentiobiose and salicin. The occurrence of reactions scored as 'weak', however, somehow hinders a clear-cut interpretation of inter-strain similarities at the level of physiological reactions. In several tests recorded, $P$. heparinus DSM $2366^{\mathrm{T}}$ showed an unexpectedly significant number of reactions that deviated from those indicated in the original description (Steyn et al., 1998). In its negative reaction towards the API and Biolog substrates, strain DSM $2366^{\mathrm{T}}$ was similar to strain WB $2.3-71^{\mathrm{T}}$. Of the reactions listed in Table 1 , these two strains do not have a single positive score in common, although both of them share between two and four positive scores with other representatives. Except for $P$. heparinus DSM $2366^{\mathrm{T}}$ and $P$. africanus DSM $12126^{\mathrm{T}}$, none of the strains investigated were heparinase-positive. The presence of phenotypic differences observed among the isolates confirms their distinct phylogenetic position determined by $16 \mathrm{~S}$ rRNA gene sequence analysis and, where done, by DNA-DNA reassociation experiments. It is concluded that the five WB isolates each represents a novel species in the genus Pedobacter; descriptions are given below.

\section{Description of Pedobacter duraquae sp. nov.}

Pedobacter duraquae (dur.a'quae. L. adj. durus, $-a,-u m$ hard; L. fem. n. aqua water; N.L. gen. fem. n. duraquae from/of hard water).
Gram-negative rods, $1.9-2.5 \times 0.63-0.83 \mu \mathrm{m}$, motile and non-spore-forming. Grows at $9-32{ }^{\circ} \mathrm{C}$; optimum growth at $25-27^{\circ} \mathrm{C}$. Grows at pH $5.70-8.15$. Weak growth in $4 \%$ $\mathrm{NaCl}$. Colonies on R2A, TSA and NA media are circular, butyrous, opaque, smooth, entire and non-pigmented. Colonies are ivory white and convex $(0.1 \mathrm{~mm}$ in diameter) on R2A, sand yellow ( $0.4 \mathrm{~mm}$ in diameter) and raised on TSA, and translucent and flat $(0.2 \mathrm{~mm}$ in diameter $)$ on NA. Microaerophilic. Hydrolyses DNA. Positive for valine arylamidase, $\beta$-glucuronidase, $\alpha$-glucosidase and $\beta$-glucosidase and weak for esterase (C4) and chymotrypsin (API ZYM). Positive for amygdalin, D-arabinose, D-ribose, Dxylose, D-adonitol, gentiobiose, inulin, L-rhamnose, salicin, D-fructose, D-galactose, sucrose and D-raffinose (API 50 $\mathrm{CH}$ and API 20NE). Positive for $\alpha$-cyclodextrin and dextrin and negative for D-raffinose (Biolog). Additional reactions are listed in Table 1 and Supplementary Table S1.

The type strain, WB $2.1-25^{\mathrm{T}} \quad\left(=\mathrm{DSM} \quad 19034^{\mathrm{T}}=\mathrm{CIP}\right.$ $109481^{\mathrm{T}}$ ), was isolated from a site about $180 \mathrm{~m}$ downstream of the spring of the Westerhöfer Bach, Westerhof, $40 \mathrm{~km}$ north of Göttingen, Germany $\left(51^{\circ} 45^{\prime} 49^{\prime \prime} \mathrm{N} 10^{\circ} 05^{\prime}\right.$ $\left.31.7^{\prime \prime} \mathrm{E}\right)$.

\section{Description of Pedobacter hartonius sp. nov.}

Pedobacter hartonius (har.to' ni.us. M.L. masc. n. Harto the Harz, a mountain range in northern Germany; N.L. masc. adj. hartonius pertaining to the Harz).

Gram-negative rods, $1.5-2.5 \times 0.63-0.83 \mu \mathrm{m}$, motile and non-spore-forming. Grows at $6-26{ }^{\circ} \mathrm{C}$; optimum growth at $12-16{ }^{\circ} \mathrm{C}$. Grows at pH 5.7-7.8 and in $4 \% \mathrm{NaCl}$. Colonies on R2A, TSA and NA media are circular, butyrous, convex, opaque, smooth, entire and non-pigmented. Colonies are pearl white $(0.1 \mathrm{~mm}$ in diameter) on R2A and sand yellow $(0.4 \mathrm{~mm}$ in diameter) and ivory white $(0.1 \mathrm{~mm}$ in diameter) on TSA and NA, respectively. Microaerophilic. Hydrolyses gelatin. Positive for $\alpha$-glucosidase and weak for esterase (C4) and $\beta$-glucosidase (API ZYM). Positive for amygdalin, D-arabitol, D-xylose, gentiobiose, L-rhamnose, salicin, $N$-acetyl-D-glucosamine, D-fructose, D-mannitol and D-galactose (API $50 \mathrm{CH}$ and API 20NE). Positive for methyl $\beta$-D-glucoside and $\alpha$-D-lactose, weak reactions with dextrin, L-arabinose and lactulose, and negative for Dmannitol (Biolog). Additional reactions are listed in Table 1 and Supplementary Table S1. 
The type strain, WB $3.3-3^{\mathrm{T}} \quad\left(=\mathrm{DSM} \quad 19033^{\mathrm{T}}=\mathrm{CIP}\right.$ $109468^{\mathrm{T}}$ ), was isolated from a site about $250 \mathrm{~m}$ downstream of the spring of the Westerhöfer Bach, Westerhof, $40 \mathrm{~km}$ north of Göttingen, Germany ( $51^{\circ} 45^{\prime} 49^{\prime \prime} \mathrm{N} 10^{\circ} 05^{\prime}$ $\left.31.7^{\prime \prime} \mathrm{E}\right)$.

\section{Description of Pedobacter metabolipauper sp. nov.}

Pedobacter metabolipauper [me.ta'bo.li.pau'per. N.L. n. metabolismus metabolism (word stem metabol-); L. masc. adj. pauper poor; N.L. masc. adj. metabolipauper metabolically poor].

Gram-negative rods, $1.7-2.7 \times 0.83 \mu \mathrm{m}$, motile and nonspore-forming. Grows at $8-31{ }^{\circ} \mathrm{C}$; optimum growth at $24-$ $26{ }^{\circ} \mathrm{C}$. Grows at $\mathrm{pH}$ 5.9-8.0. No growth in $4 \% \mathrm{NaCl}$. No growth on TSA. Colonies on R2A and NA media are $0.1 \mathrm{~mm}$ in diameter, ivory white, circular, butyrous, raised, opaque, smooth and entire. Colonies are non-pigmented. Microaerophilic. Hydrolyses DNA weakly. Positive for trypsin and $\alpha$-glucosidase and weak for esterase (C4) and chymotrypsin (API ZYM). Positive for gentiobiose, methyl $\alpha$-D-mannopyranoside and sucrose (API $50 \mathrm{CH}$ and API 20NE). Negative for sucrose (Biolog). Additional reactions are listed in Table 1 and Supplementary Table S1.

The type strain, WB $2.3-71^{\mathrm{T}} \quad\left(=\mathrm{DSM} \quad 19035^{\mathrm{T}}=\mathrm{CIP}\right.$ $\left.109480^{\mathrm{T}}\right)$, was isolated from a site about $180 \mathrm{~m}$ downstream of the spring of the Westerhöfer Bach, Westerhof, $40 \mathrm{~km}$ north of Göttingen, Germany ( $51^{\circ} 45^{\prime} 49^{\prime \prime} \mathrm{N} 10^{\circ} 05^{\prime}$ $\left.31.7^{\prime \prime} \mathrm{E}\right)$.

\section{Description of Pedobacter westerhofensis sp. nov.}

Pedobacter westerhofensis (wes.ter.ho.fen'sis. N.L. masc. adj. westerhofensis pertaining to Westerhof, a village in the Harz Mountains).

Gram-negative rods, $1.7-2.5 \times 0.83-1.0 \mu \mathrm{m}$, motile and non-spore-forming. Grows at $9-28{ }^{\circ} \mathrm{C}$; optimum growth at $22-24{ }^{\circ} \mathrm{C}$. Grows at $\mathrm{pH} 5.3-7.8$. No growth in $4 \% \mathrm{NaCl}$. Colonies on R2A, TSA and NA media are $0.1-0.2 \mathrm{~mm}$ in diameter, pearl white, circular, butyrous, convex, opaque, smooth and entire. Colonies are non-pigmented. Microaerophilic. Hydrolyses gelatin. Hydrolyses DNA weakly. Positive for $\alpha$-glucosidase and $\beta$-glucosidase (API ZYM). Positive for D-xylose, gentiobiose, L-rhamnose, methyl $\alpha$-D-mannopyranoside, D-galactose, sucrose and Draffinose and weak reactions with $N$-acetyl-D-glucosamine (API $50 \mathrm{CH}$ and API 20NE). Positive for dextrin, $\alpha$-Dlactose, lactulose, methyl $\beta$-D-glucoside and L-serine, weak reactions with $\alpha$-cyclodextrin, $\mathrm{L}$-arabinose, psicose and $\mathrm{L}$ threonine, and negative for D-raffinose (Biolog). Additional reactions are listed in Table 1 and Supplementary Table S1.

The type strain, WB $3.3-22^{\mathrm{T}} \quad\left(=\mathrm{DSM} \quad 19036^{\mathrm{T}}=\mathrm{CIP}\right.$ $109479^{\mathrm{T}}$ ), was isolated from a site about $250 \mathrm{~m}$ downstream of the spring of the Westerhöfer Bach, Westerhof,
$40 \mathrm{~km}$ north of Göttingen, Germany $\left(51^{\circ} 45^{\prime} 49^{\prime \prime} \mathrm{N} 10^{\circ} 05^{\prime}\right.$ $\left.31.7^{\prime \prime} \mathrm{E}\right)$.

\section{Description of Pedobacter steynii sp. nov.}

Pedobacter steynii (stey'ni.i. N.L. gen. masc. n. steynii of/ from Steyn, named after P. L. Steyn, the microbiologist who described the genus Pedobacter).

Gram-negative rods, $1.70-3.75 \times 0.83 \mu \mathrm{m}$, motile and nonspore-forming. Grows at $10-30{ }^{\circ} \mathrm{C}$; optimum growth at $25-27{ }^{\circ} \mathrm{C}$. Grows at $\mathrm{pH}$ 5.70-8.45. Weak growth in $4 \%$ $\mathrm{NaCl}$. Colonies on R2A, TSA and NA media are circular, butyrous, convex (raised on NA), opaque, smooth, entire, non-pigmented and slimy. Colonies are $0.4 \mathrm{~mm}$ in diameter and pearl white on $\mathrm{R} 2 \mathrm{~A}$, and $0.2 \mathrm{~mm}$ in diameter and ivory white on TSA and NA media. Microaerophilic. Hydrolyses casein, DNA and gelatin. Positive for esterase (C4), valine arylamidase and $\alpha$-glucosidase (API ZYM). Positive for protease gelatin, D-xylose, gentiobiose, salicin, D-galactose, $\mathrm{N}$-acetyl-D-glucosamine, D-raffinose, glycerol and glycogen (API $50 \mathrm{CH}$ and API 20NE). Positive for $\alpha$ cyclodextrin, dextrin, $\alpha$-D-lactose, methyl $\beta$-D-glucoside, Lglutamic acid, L-serine and L-threonine, weak reactions with D-glucuronic acid and succinic acid, and negative for D-raffinose (Biolog). Additional reactions are listed in Table 1 and Supplementary Table S1.

The type strain, WB $2.3-45^{\mathrm{T}} \quad\left(=\mathrm{DSM} \quad 19110^{\mathrm{T}}=\mathrm{CIP}\right.$ $\left.109507^{\mathrm{T}}\right)$, was isolated from a site about $180 \mathrm{~m}$ downstream of the spring of the Westerhöfer Bach, Westerhof, $40 \mathrm{~km}$ north of Göttingen, Germany ( $51^{\circ} 45^{\prime} 49^{\prime \prime} \mathrm{N} 10^{\circ} 05^{\prime}$ $\left.31.7^{\prime \prime} \mathrm{E}\right)$.

\section{Acknowledgements}

This project is part of the Research Unit 571 'Geobiology of Organoand Biofilms', funded by the German Research Foundation (Sta 184/ 19-2; DFG-FOR 571; publication 12). We thank Hans Trüper for his advice on the nomenclature of the novel species. The technical advice of Brian J. Tindall (menaquinone analysis), Anja Frühling (phenotypic tests) and Gabriele Pötter (fatty acid analysis) is highly appreciated.

\section{References}

Bernardet, J. F., Nakagawa, Y. \& Holmes, B. (2002). Proposed minimal standards for describing new taxa of the family Flavobacteriaceae and emended description of the family. Int J Syst Evol Microbiol 52, 1049-1070.

Brambilla, E., Päuker, O., Cousin, S., Steiner, U., Reimer, A. \& Stackebrandt, E. (2007). High phylogenetic diversity of Flavobacterium spp. isolated from a hardwater creek, Harz Mountains, Germany. Org Divers Evol 7, 145-154.

Cashion, P., Holder-Franklin, M. A., McCully, J. \& Franklin, M. (1977). A rapid method for the base ratio determination of bacterial DNA. Anal Biochem 81, 461-466.

Cousin, S., Päuker, O. \& Stackebrandt, E. (2007). Flavobacterium aquidurense sp. nov. and Flavobacterium hercynium sp. nov., from a hard-water creek. Int J Syst Evol Microbiol 57, 243-249. 
De Ley, J., Cattoir, H. \& Reynaerts, A. (1970). The quantitative measurement of DNA hybridization from renaturation rates. Eur $J$ Biochem 12, 133-142.

De Soete, G. (1983). A least squares algorithm for fitting additive trees to proximity data. Psychometrika 48, 621-626.

DSMZ (2001). DSMZ Catalogue of Strains, 7th edn. Braunschweig: Deutsche Sammlung von Mikroorganismen und Zellkulturen GmbH.

Escara, J. F. \& Hutton, J. R. (1980). Thermal stability and renaturation of DNA in dimethyl sulfoxide solutions: acceleration of the renaturation rate. Biopolymers 19, 1315-1327.

Felsenstein, J. (1993). PHYLIP (phylogeny inference package), version 3.5.1. Distributed by the author. Department of Genome Sciences, University of Washington, Seattle, USA.

Gallego, V., Garcia, M. T. \& Ventosa, A. (2006). Pedobacter aquatilis sp. nov., isolated from drinking water, and emended description of the genus Pedobacter. Int J Syst Evol Microbiol 56, 1853-1858.

Gerhardt, P., Murray, R. G. E., Costilow, R. N., Nester, E. W., Wood, W. A., Krieg, N. R. \& Phillips, G. R. (editors) (1981). Manual of Methods for General Bacteriology. Washington, DC: American Society for Microbiology.

Huß, V. A. R., Festl, H. \& Schleifer, K. H. (1983). Studies on the spectrophotometric determination of DNA hybridization from renaturation rates. Syst Appl Microbiol 4, 184-192.

Hwang, C. Y., Choi, D. H. \& Cho, B. C. (2006). Pedobacter roseus sp. nov., isolated from a hypertrophic pond, and emended description of the genus Pedobacter. Int J Syst Evol Microbiol 56, 1831-1836.

Kämpfer, P. \& Kroppenstedt, R. M. (1996). Numerical analysis of fatty acid patterns of coryneform bacteria and related taxa. Can J Microbiol 42, 989-1005.

Margesin, R., Spröer, C., Schumann, P. \& Schinner, F. (2003). Pedobacter cryoconitis sp. nov., a facultative psychrophile from alpine glacier cryoconite. Int J Syst Evol Microbiol 53, 1291-1296.

Miller, L. T. (1982). A single derivatization method for bacterial fatty acid methyl esters including hydroxy acids. J Clin Microbiol 16, 584-586.

Minnikin, D. E., O’Donnell, A. G., Goodfellow, M., Alderson, G., Athalye, M., Schaal, A. \& Parlett, J. H. (1984). An integrated procedure for the extraction of bacterial isoprenoid quinones and polar lipids. J Microbiol Methods 2, 233-241.

NCCLS (2000). Performance Standards for Antimicrobial Disk Susceptibility Tests, 7th edn. Approved standard M2-A7. Wayne, PA: NCCLS.

Rainey, F. A., Ward-Rainey, N., Kroppenstedt, R. M. \& Stackebrandt, E. (1996). The genus Nocardiopsis represents a phylogenetically coherent taxon and a distinct actinomycete lineage: proposal of Nocardiopsaceae fam. nov. Int J Syst Bacteriol 46, 1088-1092.
Shivaji, S., Chaturvedi, P., Reddy, G. S. N. \& Suresh, K. (2005). Pedobacter himalayensis sp. nov., from the Hamta glacier located in the Himalayan mountain ranges of India. Int J Syst Evol Microbiol 55, 1083-1088.

Somvanshi, V. S., Lang, E., Ganguly, S., Swiderski, J., Saxena, A. K. \& Stackebrandt, E. (2006). A novel species of Xenorhabdus, family Enterobacteriaceae: Xenorhabdus indica sp. nov., symbiotically associated with entomopathogenic nematode Steinernema thermophilum Ganguly and Singh, 2000. Syst Appl Microbiol 29, 519-525.

Stackebrandt, E. \& Ebers, J. (2006). Taxonomic parameters revisited: tarnished gold standards. Microbiol Today 33, 152-155.

Stackebrandt, E., Lang, E., Cousin, S., Päuker, O., Brambilla, E., Kroppenstedt, R. M. \& Lünsdorf, H. (2007). Deefgea rivuli gen. nov., sp. nov., a member of the class Betaproteobacteria. Int J Syst Evol Microbiol 57, 639-645.

Steyn, P. L., Pot, B., Segers, P., Kersters, K. \& Joubert, J. J. (1992). Some novel aerobic heparin-degrading bacterial isolates. Syst Appl Microbiol 15, 137-143.

Steyn, P., Joubert, J. J., Segers, P., Pot, B., Vancanneyt, M., Willems, A., Hoste, B. \& Kersters, K. (1993). The taxonomic position of some Gram-negative aerobic heparinase producing bacteria. In Advances in the Taxonomy and Significance of Flavobacterium, Cytophaga and Related Bacteria, pp. 137-151. Edited by P. J. Jooste. Bloemfontein, South Africa: University of Orange Free State Press.

Steyn, P. L., Segers, P., Vancanneyt, M., Sandra, P., Kersters, K. \& Joubert, J. J. (1998). Classification of heparinolytic bacteria into a new genus, Pedobacter, comprising four species: Pedobacter heparinus comb. nov., Pedobacter piscium comb. nov., Pedobacter africanus sp. nov. and Pedobacter saltans sp. nov. Proposal of the family Sphingobacteriaceae fam. nov. Int J Syst Bacteriol 48, 165-177.

Takeuchi, M. \& Yokota, A. (1992). Proposals of Sphingobacterium faecium sp. nov., Sphingobacterium piscium sp. nov., Sphingobacterium heparinum comb. nov., Sphingobacterium thalpophilum comb. nov., and two genospecies of the genus Sphingobacterium and synonymy of Flavobacterium yabuuchiae and Sphingobacterium spiritivorum. J Gen Appl Microbiol 38, 465-482.

Ten, L. N., Liu, Q.-M., Im, W.-T., Lee, M., Yang, D.-C. \& Lee, S.-T. (2006). Pedobacter ginsengisoli sp. nov., a DNase-producing bacterium isolated from soil of a ginseng field in South Korea. Int J Syst Evol Microbiol 56, 2565-2570.

Vanparys, B., Heylen, K., Lebbe, L. \& De Vos, P. (2005). Pedobacter caeni sp. nov., a novel species isolated from a nitrifying inoculum. Int J Syst Evol Microbiol 55, 1315-1318.

Yoon, M.-H., Ten, L. N., Im, W.-T. \& Lee, S. T. (2007). Pedobacter panaciterrae sp. nov., isolated from soil in South Korea. Int J Syst Evol Microbiol 57, 381-386.

Zimmermann, J. J., Langer, R. \& Cooney, C. L. (1990). Specific plate assay for bacterial heparinase. Appl Environ Microbiol 56, 3593-3594. 